\title{
Examining the Impact of Ethical Leadership on Employees' Ethical Behavior: The Role of Organizational Justice and Employees' Moral Identity
}

\author{
Hussam Al Halbusi ${ }^{1 *}$, Mohd Nazari Bin Ismail ${ }^{1}$, Safiah Binti Omar ${ }^{1}$ \\ ${ }^{1}$ Faculty of Business and Accountancy, Department of Business Strategy and Policy, \\ University of Malaya, 50603 Kuala Lumpur, MALAYSIA \\ *Corresponding Author
}

DOI: https://doi.org/10.30880/jtmb.2019.06.02.004

Received 31 October 2018; Accepted 07 May 2019; Available online 30 June 2019

\begin{abstract}
This paper investigates the role of organizational justice and moral identity of employees on the relationship between ethical leadership and employees' ethical behavior. It examines the mediation effect of organizational justice on the relationship between ethical leadership and ethical behavior of employees. This study also explores the moderating role of employees' moral identity on the relationship between organizational justice and ethical behavior of employees. Data is obtained from a sample of 230 employees from the banking industry in Iraq. The theoretical and practical contribution as well as recommendations for further research are also presented.
\end{abstract}

Keywords: Ethical Leadership, Organizational Justice, Moral Identity, Employees ethical Behavior, Ethical Behavior.

\section{Introduction}

Business ethics and ethical behavior at organization are now of interest to many academic researchers, practitioners, regulators and government officers. For them business ethics is a serious issue due to the many corporate scandals that have occurred in recent years (Mehta, 2003; Manz et al., 2008; Treviño et al., 2014). Research findings showed that people who are lacking in ethical behavior would want to fulfill their self-desires at the expense of their organizations (Schaubroeck et al., 2007; Padilla et al., 2007).

As has been addressed by Trevino and Brown (2004) the issues of ethical behavior and unethical behavior have existed since time immemorial. However, nowadays the issue of ethical behavior of employees is becoming a pressing worldwide issue. Moreover, it is also one of the most important and most frequent subjects of business ethics research since it is very critical and essential for organizations to implement socially responsible and ethical business practices. The subject of organizational behavior is regarded as a function of an organization's employees (Ones \& Dilchert, 2012b; Wiernik, Ruger, \& Ones, 2018). Employee responsible behaviors are individual-level employee actions that contribute to or detract from corporate social, ethical, and environmental performance. The establishment of ethical behaviors requires guidance and clear values and structures which is very critical to set up.

The growing interest of researchers on the role of ethical leadership has prompted efforts not only to minimize cases of misbehaviors, but also to improve and to set ethical standards in organizations (Mayer et al., 2009; Neubert et al., 2009; Brown and Trevino 2006; Sama and Shoaf, 2008; Treviño et al., 2014). Ofori, (2009) \& Brown, et al., (2014), asserted that leaders should exercise the greatest ethical standards and good conducts in their everyday dealings, 
actions, judgments in order to be a good example and role model to their subordinates. Prior literature on ethical leadership have constantly highlighted the importance of understanding the role of ethical leadership in demonstrating employees' ethical behavior (Ofori, 2009; Brown et al., 2005; Certuche, et al., (2019).

Also, organizational justice has been reported as one of the most important factors which has an essential impact on ethical behavior of employees (Ambrose and Schminke, 2009; Colquitt, 2001). Rawls (1971) pointed out that organizational justice is a fundamental value and virtue which is also the main ethical concern of employees. Skitka and Bauman, (2008) and Folger et al., (2005), stressed that justice is deeply rooted in every person's moral assumption.

Organizational justice, also known as inputs and outputs, according to justice studies is concerned with the twoway relationships between employer and employees in an organization. Even though organizational justice has been examined by numerous researchers, however, mainstream researchers only concentrated on the consequences of organizational justice. Only some studies focused on ethical leadership behavior as vital antecedents of organizational justice (Demirtas, 2015; Xu, 2016). In addition, Loi, et al., (2012) \& Karam, et al., (2019) reasoned that the quality of fairness is fundamental to employees' behavior.

Furthermore, cases pertaining to ethical issues revealed that whenever managers are found to practice unethical behavior, the followers will question their managers' background and also will query whether the rules and guidelines of the organization can be relied upon (Premeaux, 2009, Demirtas, 2015). Therefore, theoretically and practically, it is extremely significant to scrutinize the reasons how and why such ethical leadership behavior can impact the perception of employees' fairness towards the organization. Irrespective of the relationship between ethical leadership and ethical behavior of employees, management researchers have neglected the role of organizational justice as essential mechanisms in influencing the association of ethical leadership and ethical behavior of employees.

Apart from the above-mentioned issues, there is also a need to study moral identity which is predominantly concerned with employees' behavior. Previous studies have shown that moral identity influences people's behavior (Tanghe et al., 2010; Nelissen et al., 2007; Treviño et al., 2014). Thus, this research is also intended to investigate the moderating role of moral identity on the relationship between organizational justice and employee's ethical behavior.

\section{Theoretical background and Hypothesis Development}

\subsection{Definition of Ethical Behavior}

A large amount of literature has been dedicated to ethics literature over the past few decades. In July 2018, a search in the web of science database (WOS) "Ethics" received overwhelming attention in the categories of "book" "articles" and "conference". The search listed the details of more than 346 publications for the last ten years. Generally, despite the importance of ethics in various disciplinary literature, there is still no universally accepted definition of ethics. The ambiguity of the concept of ethics is due to its many diverse definitions, which range from being highly specific to very broad (Tenbrunsel et al., 2008). Every one of the meaning may disclose some significant aspects of ethics, but above all, the most usual aspect is that the studies are focused on behavior as an essential part of ethics. Behavior, in this respect, may refer to anything that is perceived as a good act or the right behavior by individuals in a particular situation, or it may vary from organization to organization depending on how the behavior is introduced. Fraedrich (1993, p. 207) "considered ethics as 'right behavior' in the social setting in which it is introduced (an individual, group, firm, industry, wider society)”.

\subsection{Ethical Leadership and Employee's Ethical Behavior}

Leadership styles have been extensively discussed and the highest level of leadership has been referred to in various ways, for example, "Senior leadership" (Kimmel, 1981; Heller 1971), "Executive leadership" (Carlson 1951), and "Strategic Leadership" (Lu and Yang, 2010; Philips and Hunt, 1992). Burns (1978), Mayer et al., (2009). For the purpose of maintaining effective work situations and ethical standards at organizations, Brown et al., (2005) proposed the concept of 'ethical leadership behavior'. This form of leadership recognizes the importance of virtuosity and good practices. In the past, many scholars have emphasized truthfulness and honesty as the key elements for the direction of ethical manager (Brown et al., 2005). Brown and Trevino (2006) contended that scandals pertaining to ethical issues exist in the workplace such as nonprofit organizations, sports, and religious institutions where the significance of moral issues and actions of leader's manner ethical content are exposed. Brown et al., (2005) in his study defined ethical leadership as "the demonstration of normatively conducted behavior through personal actions and interpersonal relations" (p.120). As most of the studies have the agreement that ethical leadership is critical in term of integrity, honesty and principled decision-makers, this eventually led researchers to consider these features as the virtuous factor of ethical leadership (Kuntz et al., 2013; Eubanks et al., 2012).

Numerous empirical studies show that ethical leadership is related to employees' ethical behavior (Mayer et al., 2009; Stead et al., 1990). Stead et al., (1990) highlighted that leaders are representatives of an organization. They are an important factor that can influence the behavior of their subordinates. Most ethical leaders possess positive behaviors 
where they strive to influence their subordinates using clear ethical standards. Mayer et al., (2009) stated that ethical leaders can influence their employees through the exchange of socio-emotion as this form of exchange is a positive behavior which build trust between leaders and employees (Blau, 1964). Mayer et al., (2009) further added that when leaders manage their followers fairly and honestly, then their followers will be willing to trust them. On the top of that, as Abdullah, \& Halim, (2016) reported that individuals with a high work ethic will be having lower tendency to involve with ethical behavior and on the other hand individuals who have low work ethic may tend to engage in unethical behavior. This will benefit the organization as a whole.

Additional empirical evidences have indicated that ethical leadership do have influence over employees' ethical behavior (Dickson, et al., 2001; Koh and Boo 2001; Viswesvaran et al., 1998). Brown and Trevino (2006) further added that leaders are capable of supporting the employees 'ethical conduct' by encouraging and frequently communicating with them regarding ethical conduct. Albaum and Peterson (2006), Demirtas, (2015) \& Koopman, et al., (2019) stated that the moral concept and behavior of majority of the workforce can be transformed by acquiring practical moral instruction from their leaders. Based on the above, we propose the following hypothesis to be tested:

H-1: There is positive relationship between ethical leadership and ethical behavior of employees.

\subsection{Mediation: Organizational Justice}

Leaders in every organization are conferred with legal powers to manage their employees and also to take charge of organizational resources, therefore, assigning them to an exclusive position to administer justice (Brown et al., 2005). Loi et al., (2009) stressed that these managers are very often looked upon as carrying out the principal function of the organization. Another study stressed that ethical leadership may reinforce the views of its employees who perceived justice as the right way of handling ethical conduct (Lind, 2001). Employees in every organization have the tendency to consult with their leaders on ethical guidance as the performance of leaders in the working environment function as the standard role model for right conduct (Brown et al., 2005). Trevion et al stressed that managers of an organization must be impartial, righteous, honest, and reliable and have good principles when making decisions besides exercising care towards the workforce and being genuinely concerned about means rather than ends (Trevino and Brown 2007). They also stressed that managers will not only set clear moral standards and expectations, but also actively spread these moral standards and expectations to their subordinates by using rewards and disciplinary actions to motivate employees to partake in ethical conduct (Trevino and Brown 2007).

Ethical leadership has contributed to the development of positive work behavior among employees in the workplace, such as organizational commitment, performance and ethical behavior of employees (Brown et al.,2005; Brown and Trevino, 2006). Fairness is the primary concern of ethical leaders and such as this characteristic is conveyed to the employees by listening to their views and having clear and honest communication with their followers and also making fair decision (Neubert et al., 2009).

It is obvious that employees hugely care how they are treated by others. Cropanzano and Greenberg (1997); Greenberg, (1990); Angelidis and Nabil, (2011) explained that organizational justice focuses on the perceptions of fairness in the workplace. Colquitt (2001) declared that there are four components to Organizational Justice. The first component is Distributive Justice which pertains to equity theory as developed by Adams (1963). This component concerns the equal distribution of outcomes based on the performance of every individual employee (Steensma and Visser, 2007; Burney, et al., 2009). Procedural Justice is the second component and defined by Folger and Cropanzano (1998); Cropanzano et al., (2001) as: “... neutrality, status (social position or status within a group or process) and trust. Procedural Justice emphasizes on the perceived fairness of the processes i.e. procedures and policies used and their enactments of determining outcomes or resource distributions" (Greenberg, 2011; Rhodes et al., 2001; Ambrose and Schminke, 2009; Colquitt, 2001). The third component is Interpersonal justice which Bies and Moag (1986) defined as "the quality of interpersonal treatment they receive during the enactment of organizational procedures and their interaction with leaders as they treated them with respect and dignity". The last component is Informational Justice which is the "process of receiving essential information in an appropriate manner and through clear communication" Colquitt (2001). We posit that organizational justice mediates the relationship between ethical leadership and employees' ethical behavior. We consider organizational justice as crucial mechanism for two reasons.

Firstly, fairness is one of the most important characteristics of ethical leadership since ethical leaders display explicit fairness, honesty and trustworthiness. Resulting from fair practice employees working under this fair environment will very likely perceive the organization's justice to be credible. Thus, employees will have the confidence to rely on the practice of fairness to eliminate any uncertainty about their relationship with their employer and behave ethically under this fair environment. On the contrary, employees who are treated unfairly and dishonestly would definitely observe inconsistency in the leadership behavior and organizational justice. Under such situations Brown et al., (2005), and $\mathrm{Xu}$, et al., (2016) emphasized that employees have the prerogative to question whether the fairness guidelines laid down are indeed reliable information which can help the workforce to anticipate a better future. It is very unlikely that the workforce will trust this organizational justice to start a relationship with their organization 
should they find out that the fairness procedures are not adhered to. Lin, et al., (2009), Lambert, et al., (2019), Karam, et al., (2019) Al Halbusi, et al., (2019) and further explained that organizational justice is therefore, an important and vital element which employees can use to infer how they are managed by others.

Secondly, organizational justice according to Colquitt and Greenberg, (2003) and Brown et al., (2005) conveys the expectations to employees with clear procedures, and distribution of what type of treatment the employees are expected to receive. Many in-depth studies have highlighted the need for systems and customs of the organization be made known to the employees. This is especially regarding the integrity of the organization, such as making justice quite outstanding in the organizational context. In this way, employees will be inclined to accept that justice is not only important but is also the deciding factor whether an employee can continue to work in the organization.

In contrast, employees who are cynical and feel that there is unfairness and poor ethical standards in the organization are unlikely to rely on organizational justice, thereby causing them to behave in an unethical manner to achieve their aims (Brown, et al., 2005, Demirtas, 2015; Treviño et al., 2014). Based on the above arguments, these relationships were further scrutinized by proposing organizational justice as a crucial mechanism in the relationship between ethical leadership and ethical behavior of employees.

H-2: Perceived organizational justice mediates the relationship between moral leadership and good behavior of employees.

\subsection{Moderation: Moral Identity}

According to Ashforth \& Mael (1989) "moral identity is grounded in social identity theory. It is not only a social identity that comprises a person's self-concept but also a social schema that describes the self and controls ethical behavior" (Hardy \& Carlo, 2005; Kelley \& Stahelski, 1970; Hales, 1985). The study by Blasi (1984, 1990) affirmed that moral self-conception (i.e. self-importance of moral identity) is linked with ethical behaviors. Other scholars carried out further studies to gauge moral identity (such as Hart et al., 1998). Similarly, Aquino and Reed (2002) explained the concept of "moral identity by embracing a trait-based definition of moral identity as they assumed that there are commonly accepted moral traits that comprise moral values".

Aquino and Reed (2002) identified nine moral traits, known as the self-importance of moral identity (SIMI) which embraced a person's moral identity. The nine moral traits are "caring, compassion, fairness, friendly, generous, helpful, hardworking, honest and kind". According to them, people with high moral identity are inclined to reflect on their moral values that are internalized. According to Reynolds and Ceranic, (2007); Aquino and Reed (2002); Aquino et al., (2009); Bergman, (2002) people with high moral identity tend to be more caring, compassionate and honest compared to persons with low moral identity. Thus, if a person considers moral identity to be more important than others, it is very probable that this identity will be activated and will control the person's behavior in any situation.

This study considers moral identity as a moderator for the following reasons. Firstly, although the findings of earlier researchers have revealed positive results, nevertheless it has been contended in the literature that the monitoring of organizational justice has a positive and significant impact on employee behaviors (Elamin \& Alomaim, 2011; Oshio \& Kobayashi, 2009; Schyns, 2001). Moreover, Shah et al., (2017) in their research findings revealed that organizational justice's component has positive impact on the moral behavior of employees. But Trevino et al., (2014) added that recent articles have encouraged researchers to conduct further research on ethical behavior as there is still a need to strengthen the results.

Secondly, although factors generally have an impact on people's behavior, the strength of this association relies on numerous intra-individual variables (Tanghe et al., 2010; Nelissen et al., 2007). Hardy and Carlo (2005) emphasized that every individual has a set of beliefs of themselves or their own self-concept which proves to be a critical factor. A self-conception that relates to the conditions of ethical behavior pertains to an individual's moral identity which Aquino and Reed (2002) in his findings had explained as a self-conception that is focused around a cluster of moral traits. It is indeed more important for a person to be moral if he is fully focused on his own moral identity. It is, therefore, not surprising that many studies have been conducted which prove that moral identity is a forceful regulator and motivator of ethical behavior (Deteret et al., 2008; Lapsley and Lasky 2001; Shao et al., 2008; Hardy and Carlo 2005).

Many studies have also confirmed that people react to their own mistreatment by practicing unethical behavior as a way of retribution (e.g., Tepper et al., 2009; Thau and Mitchell, 2010; Holtz and Harold, 2013; Mitchell and Ambrose, 2007) but, there are other people who will deem it to be dishonest to counter to third-party mistreatment by exhibiting expected behaviors. Studies have found that persons with high moral identity are likely to have weaker tendencies to react to organizational abuses such as mistreatment or procedures by participating in unethical behavior that causes aversive effects that are tantamount to mistreating others (Tepper et al., 2009; Thau and Mitchell, 2010). Aquino and Reed, (2002); Blasi, (1984) (2004); Lapsley and Lasky; (2001) explained that when a person accepts morality as a main component of self-conceptions, it would be much convenient for him to secure this part of his identity when making moral judgments. Therefore, it can be said that the strength of a person's moral identity can influence the way a person 
reacts to and comprehend ethical choices (Shao et al., 2008) as it may affect the manner, he/she reacts to observed mistreatment. Hence, based on the prior argument, the following hypothesis has been formulated.

H-3: Moral identity moderates the relationship between organizational justice and employees' ethical behavior such that the relationship is stronger under a high level of moral identity than under a low level of moral identity.

\section{Methodology 3.1 Sample and Procedure}

In order test the research hypotheses, data were collected from employees who are currently working in the banking industry in Baghdad and in the western province of the Republic of Iraq. In order to overcome the Common Method Variance (CMV) problem, procedural and statistical remedies suggested by Podsakoff et al., (2003) and Tehseen et al., (2017) were carefully followed. Firstly, the survey questions were read and approved by 6 panel of experts in this area of leadership. Pre-testing via cognitive interviews were carried out. Respondents were also given explanations for each of the constructs with clear directions on how to complete the evaluation of items so as to avoid any confusion. Respondents were reassured of the confidentiality of their identities as well as the academic nature of the study.

In addition, a psychological separation among measurements was done where a social desirability construct known as "Marker variable" was utilized for statistical remedy purpose. Chin et al., (2013) recommended the measured latent marker variable (MLMV) method to identify and correct CMV when using partial least squares as the researchers have planned prior to data collection. The questionnaires were distributed to 265 employees and 230 of them were completed and usable giving a response rate of 87 percent.

\subsection{Measurement}

In this study, since the respondents were all Arab speakers, all the items in the questionnaire were translated from English to Arabic. Prior translating to Arabic, the researchers ensured that the contents of the English version were accurate, understandable and acceptable. The questionnaire was translated according to the "Double blinded principle" (Brislin 1980) where the original English version was translated into Arabic, and the Arabic translated version was then translated back into English by two researchers who are familiar with the field of leadership to guarantee their validity.

The questionnaire consists of four parts: ethical leadership; organizational justice; moral identity and ethical behavior. Flynn et al., (1990) suggested that the utilization of any existing scales used in earlier published studies will assure validity and reliability. Accordingly, in this study, items were adapted from the following earlier studies of (Brown et al., 2005; Aquino and Reed, 2002; Colquitt, 2001; Lu, C. S., \& Lin, and C. C., 2014).

\subsubsection{Ethical leadership}

Ethical leadership can be assessed using the six ethical leadership evaluation elements which were taken from Brown et al., (2005), namely: Treating employee fairly, Listening, Concerning, Trust, Behavior model and Communication response. Ethical leadership involves 10 items. Example of the items "My supervisor listened to what employees have to say". The response format is " 5 -Likert Scale ranging from ' $1=$ Strongly Disagree' to ' $5=$ Strongly Agree".

\subsubsection{Organizational Justice}

Organizational justice has been assessed by twenty items adapted from Colquitt's (2001) scale for employees' perception in the workplace. The twenty items refer to "distributive justice", "procedural justice", "interpersonal justice" and "informational justice." The four types of equality pertaining to organizations are classified as follows: Distributive Justice, was measured by using four items which concentrate more on equal payment, promotion, sufficient recognition, and rewards. Sample of item "Does your outcome reflect the effort you have put into your work". Procedural Justice, a seven-item scale was adapted for this variable. It measures the procedures/practices fairness in the workplace and to what extent the procedures are equally and consistently applied to everyone. Sample items are "Have you been able to express your views and feelings during those procedures". Interpersonal Justice was measured using a four-item scale regarding employees' interaction with their superior at the workplace such as how their supervisor treats them in a polite manner, with dignity and with respect. Sample of item is "Has your superior treated you in a polite manner?". For Informational justice, the following five items refer to the authority figure who enacted the procedure in respect of the information being provided. The sample item is "Were your superior's explanations regarding the procedures reasonable". All The response of organizational justice dimensions format is " 5 Likert Scale with anchors of ' 1 = To a Small Extent' to ' 5 = To a Large Extent". 


\subsubsection{Moral identity}

To measure moral identity of self-importance, moral identity (SIMI) five items were used which adapted from (Aquino and Reed, 2002). These items were clearly reported in the literatures and were broadly utilized by the previous studies (Reed and Aquino, 2003; Hardy and Carlo, 2005). Example of the items "It would make me feel good to be a person who possess these characteristics". The main measurement of moral identity is responded on a "5-Point Likert Scale 1=Strongly Disagree to 5=Strongly Agree".

\subsubsection{Ethical Behavior}

Ethical behavior is referred to as an employee's ethical behavior in their organization. To assess this construct, sixteen items have been adapted from past studies (Ferrell et al., 2000; Lu, C. S., \& Lin, C. C., 2014). An example of the items "I am careful with company materials and supplies". The response format is " 5 -Likert Scale ranging from $1=$ Strongly Disagree' to '5= Strongly Agree”.

\subsubsection{Social Desirability}

This variable was used as a "Marker variable" as this variable theoretically is not related to the research framework in the given study. However, this variable has been used to statistically control the Common Method Variance (CMV). It contains 7 items, which were adapted from (Fischer and Fick, 1993; Crowne \& Marlowe, 1960). An example of the items "I have never been annoyed when people expressed ideas which are very different from my own". Cognitive rigidity is responded on a "5- point Likert scale 1=Strongly Disagree to 5=Strongly Agree".

\section{Results and Finding}

In this research, the Structural Equation Modeling (SEM) through Partial Least Squares (PLS) method was conducted for the purpose of analyzing the research model using SmartPLS 3.0 software (Ringle et al., 2015). Descriptive analysis was performed and followed by measured latent marker variable (MLMV) method to identify and correct CMV (Chin et al., 2013). Firstly, Anderson \& Gerbing (1988) and Hair et al., (2017), recommended to apply two analytical techniques; starting with the evaluation of the measurement model (validity and reliability), and followed by the structural model assessment (hypothesis relationship testing). A two-step assessment approach process, which comprise both the measurement model and structural model, has advantages on the one-step (Schumacker \& Lomax, 2004; Hair et al., 2010). Hair et al., (2017) has clearly mentioned that, the measurement model indicates how each of the constructs measure, in order to explain the relationship among variables the structural model will indicate how each of the constructs are related to each other. For this present study, the PLS statistical method has been chosen because PLS possess features that can simultaneously analyze the measurement model and structural model so as to give a better and more accurate estimation (Barclay et al., 1995).

\subsection{Demographic Analysis of Respondent}

This section covers the demographic information of respondents which was performed by SPSS version 21 . As revealed, $67.4 \%$ of the respondents were male and $32.6 \%$ are female. In term of age the highest score was for employee's range between 31 and 40, 34.8\%. In terms of marital status of employees, $20.4 \%$ are single, $67.0 \%$ are married, $6.5 \%$ are widowed, and $6.1 \%$ are divorced. In regard of educational background people holds bachelor's Degree were the highest number gained 52.2\%. Monthly Income, employees receiving amount among 450,000549,999 were the highest which was $30.0 \%$. In terms of job experience, employees working between 6-10 years, obtained the scored $39.1 \%$. The details are illustrated in the (Appendix A).

As mentioned earlier, since the data were collected from one single source, the researchers have applied statistical remedies to minimize the Common Method Variance (CMV). The researchers drew a hypothesized model using Smart PLS software and observed the initial $\mathrm{R}^{2}$ value of endogenous constructs (see Appendix B, Figure.1). Then we assigned the "Marker Variable" on the endogenous constructs and again observed the $\mathrm{R}^{2}$ value (see Appendix B Figure.2). Then the researchers were compared between the initial $\mathrm{R}^{2}$ value of endogenous constructs prior and after adding the "Marker Variable" as the revealed for the Ethical Behavior (e.g., 0.473-0.520), and for the Organizational justice (e.g., 0.314-0.318). Thus, the diff erence was found in the $\mathrm{R}^{2}$ value of endogenous constructs after partialling out the Marker Variable which is not significantly different as presented in the Table 1, which is less than 10\% (Podsakoff et al., 2003; Chin et al., 2013). This result has provided another clue for the no substantial common method bias in this research. 
Table 1 - Statistical Remedy of Common Method Variance (CMV)

\begin{tabular}{ccc}
\hline Factors & $\begin{array}{c}\mathbf{R}^{\mathbf{2}} \\
\text { Not including Marker Variable }\end{array}$ & $\begin{array}{c}\mathbf{R}^{\mathbf{2}} \\
\text { Including Marker Variable }\end{array}$ \\
\hline Ethical Behavior & 0.473 & 0.520 \\
Organizational Justice & 0.314 & 0.318 \\
\hline
\end{tabular}

Note: the change of the value of the R2 should be less 0.10

\subsection{Measurement Model}

To assess the measurement model, we examined the internal consistency reliability, convergent validity, and discriminant validity. To evaluate the internal consistency of the measurement scale, Composite Reliability (CR) was utilized in the given study. The ranging of the CR was from 0.803 to 0.932 which achieved the acceptable level of 0.07 , hence the indication of the internal consistency reliability is established (Hair et al., 2017). The Average Variance Extracted (AVE) was conducted to measure the convergent validity. The evidence of the convergent validity was confirmed because the AVE for the all constructs exceeded the threshold which ranged from (0.512 to 0.872) (Hair et al., 2017). as presented in measurement model (see Appendix C).

Furthermore, in recent literatures, the Fornell-Larcker criterion has been strongly criticized because it does not accurately reveal the lack of discriminant validity in common research situations (Henseler et al., 2015). Alternatively, it was suggested to use the technique, Heterotrait-Monotrait Ratio (HTMT) of correlations and based it on the Multitrait-Multimethod Matrix. Hence, in this study HTMT was employed to assess the discriminant validity. There is a problem with the discriminant validity when the HTMT value is greater than HTMT0.90 value of 0.90 (Gold et al., 2001) Besides that the HTMT0.85 value of 0.85 (Kline, 2010), as revealed in Table 2, indicates that the determined discriminant validity was lower than the recommended value of 0.85 .

Table 2 - Discriminate Validity through HTMT

\begin{tabular}{ccccc}
\hline Constructs & EB & EL & MI & OJ \\
\hline EB & 0.676 & & & \\
EL & 0.588 & 0.744 & & \\
MI & 0.506 & 0.35 & 0.787 & 0.546 \\
OJ & 0.552 & 0.56 & 0.489 & \\
\hline
\end{tabular}

Note: $\mathrm{EB}=$ Ethical Behavior, EL= Ethical Leadership, MI= Moral Identity, OJ= Organizational Justice.

\subsection{Structural model}

Recently Hair et al., (2017) proposed the criteria for structural model measurement which can be assessed by the beta $(\beta), \mathrm{R}^{2}$ and the corresponding t-values through the bootstrapping process with re-sampling of 500. Therefore, as was suggested, the effect size $\left(\mathrm{f}^{2}\right)$ also needs to be reported. In addition, Sullivan \& Feinn (2012) cited that the p-value can be applied to establish whether the eff ect exists, but in this way, it will not disclose the size of the effect. Therefore, the research hypothesis has been examined utilizing the structural model and the level of acceptance of the path coefficients advocated by Hair et al., (2011) and Wetzels et al., (2009), whereby the 0.1 path coefficient is the minimum to have an impact on the model. The suggested significant level of the coefficients must be at least 0.05 (i.e. $95 \%$ confidence level). The significance of the hypotheses for all constructs was based on the t-values retrieved using SmartPLS Bootstrapping from the 5000 re-samples.

\section{Hypothesis 1 (Ethical Leadership \& Ethical behavior)}

As this research advocated the positive association of ethical leadership and ethical behavior of employees, the $t$ values were compared using 1-tailed test as shown in Table 3, to test the significance. As revealed form the result stated that $\mathrm{H}_{1}$ Ethical Leadership on the Employees Ethical Behavior was supported $(\beta=0.376, \mathrm{t}=4.848 ; \mathrm{p}<0.001)$. Referring to Table 3 . 


\section{Hypothesis 2 (Mediating Role)}

The mediating effect of organizational justice on the relationship of ethical leadership and ethical behavior of employees was tested according to suggestion by Hair et al., (2017) to employ the bootstrapping method used by Preacher \& Hayes (2004) and Preacher \& Hayes' (2008). Table 3, which presents the outcome of the analysis, revealed that indirect effect $\beta=0.116$ was significant with t- value of 2.594. Preacher and Hayes (2008) mentioned that when the 0.116, 95\%, CI: [LL=0. 0.037, UL=0.200] does not straddle a 0 in between, it indicates there is mediation. For this study we can conclude that the mediation effect of the organizational justice is statistically significant i.e. $\mathrm{H}_{2}$ is supported.

Table 3 - Hypothesis Testing Direct effect \& Mediation Indirect effect

\begin{tabular}{ccccccccccc}
\hline Hypothesis & Relationship & SB & SE & $\begin{array}{c}\text { t- } \\
\text { value }\end{array}$ & $\begin{array}{c}\text { p } \\
\text { values }\end{array}$ & LL & UL & Decision & $\mathbf{R}^{2}$ & $\mathbf{f}^{2}$ \\
\hline H1 & EL-> EB & 0.376 & 0.078 & 4.848 & 0.000 & 0.257 & 0.498 & Supported & 0.473 & 0.182 \\
H2 & EL-> OJ-> EB & 0.116 & 0.045 & 2.594 & 0.010 & 0.037 & 0.200 & Supported & 0.314 & 0.048 \\
\hline
\end{tabular}

Key: $\mathrm{EL}=$ Ethical Leadership, $\mathrm{EB}=$ Ethical Behavior $\mathrm{OJ}=$ Organizational Justice.

\section{Hypothesis 3 (Moderating Role of Moral Identity)}

The moderating effect of moral identity was tested by employing the orthogonalizing approach. This is to minimize the multicollinearity problem. According to Henseler \& Chin, (2010) this approach is preferred when the exogenous construct and moderator variable are measured reflectively which is the case in this study.

In carrying out moderation analysis, the $\mathrm{R}^{2}$, is an important and serious issue. According to the results, the initial $\mathrm{R}^{2}$ was 0.473 . After the interaction effect the $\mathrm{R}^{2}$ was changed to 0.507 ., the $\mathrm{R}^{2}$ changed to 0.034 indicating that with additional interaction term the $\mathrm{R}^{2}$ has changed about $3.4 \%$, which is an additional variance. Furthermore, for the $\mathrm{f}^{2}$ interpretation we followed Cohen's (1988) suggestion, hence the $\mathrm{f}^{2}$ of the given study was 0.069 which is considered as small. However, although the $\mathrm{H}_{3}$ was not significant as shown in the Table 4, nevertheless, the impact is still important. The study showed that a positive relationship exists between organizational justice and ethical behavior and that employee's ethical behavior is stronger the higher the level of moral identity.

Table 4 - Moderation Testing

\begin{tabular}{ccccccccc}
\hline Hypothesis & Relationship & SB & SE & t- value & p value & LL & UL & Decision \\
\hline H3 & OJ*MI -> EB & -0.219 & 0.267 & 0.819 & 0.207 & -0.395 & 0.33 & Not Supported \\
\hline
\end{tabular}

Key: OJ*MI -> EB= Organizational Justice*Moral Identity-> Ethical Behavior.

\section{Discussion}

The aim of this research is to identify the important factors that have an impact on ethical behavior of employees. From the findings, the main three components are ethical leadership, organizational justice and moral identity were identified as crucial components. As revealed form the results ethical leadership and organizational justice were found to be significant, whereas moral identity is not. The organizations in the new millennium have been loaded with a hard task in the new era of ethical scandals. Apart from that, the organization requires highly committed people, who possess integrity and transparency. Such organizations require appropriate behavior on the part of employees for the overall development of the organization so as to maintain their competitiveness and to continue to provide quality services to the community, stakeholders and customers.

The study revealed that ethical leadership behavior and organizational justice are significant, while moral identity is not. It can be stated that employees have substantial interaction with their leaders in the workplace where some leaders are so sociable and have great relationship with their followers outside the organization which they are working in. Close interaction and communication with supervisors, inside or outside the workplace, could build a strong relationship, which can lead to a profound effect on ethical leadership and on employees' ethical behavior. This finding is consistent with past studies (Mayer et al., 2009; Lu, C. S., \& Lin, C. C., 2014). 
In regard organizational justice, as shown in the findings, the perceive of organizational justice is an essential element to employees' ethical behavior, for instance when the followers seen the fairness in particular workplace applied consistently accurately, definitely will act ethically. Hence, the subordinates can infer their future works and psychologically they will have great perception of the organizational justice, and then led to a positive behavior. Thus, organizational justice was statistically significant to ethical behavior of employees, which is similar with the last studies (Demirtas, 2015; Shah et al., 2017; Al Halbusi, et al., 2018).

Surprisingly, moral identity as moderating variable was statistically insignificant. This finding needs to be carefully considered though. At first glance, the ethnic diversity that exists in the Iraqi workplace verified that the perceived and perceptions of moral identity are different and this varieties are indeed led to different outcomes. Iraq is considered as country has variety of ethnic. Since the responsibility and difficulty for any failure fall on an individual's shoulders, that will be different in the diversity context in term of self-regulation and self-conception which is very hard to verify in context has ethnic diversity. Moral identity is an important source for organization such as making ethical decision, taking responsibilities, having honest close communication with their leaders and peers and schedule of activities which are substantial features of moral identity based on the self-conceptions and regulatory. By the same token, this point is highlighted in the Iraqi context with ethnic diversity where, basically, the different diversity of employees may provide an unconscious prescription makes a high difference of the notions. This may turn into a serious case if any failure occurred and employees are blamed. So, based on the statistical results of this study, the moral identity may provide a great opportunity to develop a good relationship with the employee and influence their ethical conduct based on the similar diversity which need be reconsidered.

A further possible explanation according to Hofstede, G. (1984) Iraqi society is collectivist nature, so in the collectivist nature of Iraqi society; in comparison with individualistic societies, defining moral identity as selfconception and self-regulatory, this is clear for individualistic people works better rather than collectivistic. Thus, the collectivist nature could be the main reason moral identity was not supported, therefore, in a collectivism culture could noticeably disapprove the moral identity in the Iraqi context. For instance, employees feel and behave better when they have more action and interaction of individualism rather than collectivism. It must be mentioned that previous studies have shown moral identity as being statistically significant and positive relationship with ethical behavior (e.g., Nelissen et al., 2007; Tanghe et al., 2010).

\section{Research Implication and Limitation}

This study has identified two essential factors to the research model, which were not included in the previous studies such as organizational justice as mediation on the relationship of ethical leadership and employees' ethical behavior, which is the most important implication to the business's ethics literatures. In addition, this study adopted moral identity as moderator in the relationship between organizational justice and ethical behavior of employees which is a new contribution to the body of knowledge. This study is also important for practice since the findings of this research can be utilized by organizations as guidance to improve their organization process.

There are some limitations to this study. Firstly, is the relatively small number of participants. A bigger sample size will improve the findings. Second, data were collected form self-report single source. The outcomes of this research may be affected by the Common Method bias, although this study has employed procedures remedies. Furthermore, in this study the sample was not diverse in terms of demographics. Respondents were all from the banking industry in Iraq thus, the research findings may not be generalizable to other countries or cultures (Resick et al., 2006).

\section{Future Research and Conclusion}

Further research may consider more specific ethical behavior variables such as whistle-blowing, and counterproductive work behavior as outcomes. Future research could also examine individualism as moderator. Furthermore, in this study data were collected from individuals. Future studies may collect data from teams to examine ethical behavior at the group or team levels.

To conclude, ethical behavior is an important concern for any organization. It is very crucial for the management of organizations to make sure that an ethical environment exist in the workplace. This study has added to our understanding of how ethical leadership and organizational justice can improve ethical behavior standards among members of an organization. In addition, this study also highlighted the importance of appropriately matching organizational justice and ethical behavior of employees with the moral identity. Extending the theory and results of this study to other organizational contexts is certainly warranted. 
Appendix: A

Demographic Profile of Respondents.

\begin{tabular}{|c|c|c|c|}
\hline Percentage & Demographic Respondents & Frequency & $\%$ \\
\hline \multirow[t]{2}{*}{ Gender: } & Male & 155 & 67.4 \\
\hline & Female & 75 & 32.6 \\
\hline \multirow[t]{5}{*}{ Age: } & Less than 25 & 14 & 6.1 \\
\hline & $25-30$ & 57 & 24.8 \\
\hline & $31-40$ & 80 & 34.8 \\
\hline & $41-50$ & 59 & 25.7 \\
\hline & More than 51 & 20 & 8.7 \\
\hline \multirow[t]{4}{*}{ Marital Status: } & Single & 47 & 20.4 \\
\hline & Married & 154 & 67.0 \\
\hline & Widowed & 15 & 6.5 \\
\hline & Divorced & 14 & 6.1 \\
\hline \multirow[t]{5}{*}{ Education: } & High School & 31 & 13.5 \\
\hline & Diploma & 44 & 19.1 \\
\hline & Bachelor's Degree & 120 & 52.2 \\
\hline & Master's Degree & 16 & 7.0 \\
\hline & Doctorate Degree & 19 & 8.3 \\
\hline \multirow[t]{7}{*}{ Monthly Income: } & 149,000 or Less & 2 & 0.9 \\
\hline & $150,000-249999$ & 2 & 0.9 \\
\hline & $250,000-349,999$ & 9 & 3.9 \\
\hline & $350,000-449,999$ & 40 & 17.4 \\
\hline & $450,000-549,999$ & 69 & 30.0 \\
\hline & $550,000-649,999$ & 66 & 28.7 \\
\hline & 650,000 or above & 42 & 18.3 \\
\hline \multirow[t]{5}{*}{ Job Experience: } & 2 Years or Less & 14 & 6.1 \\
\hline & $3-5$ Years & 45 & 19.6 \\
\hline & $6-10$ Years & 90 & 39.1 \\
\hline & $11-15$ Years & 31 & 13.5 \\
\hline & 16 Years or More & 50 & 21.7 \\
\hline
\end{tabular}


Appendix B: The Assessment of The Common Method Variance by Marker Variable

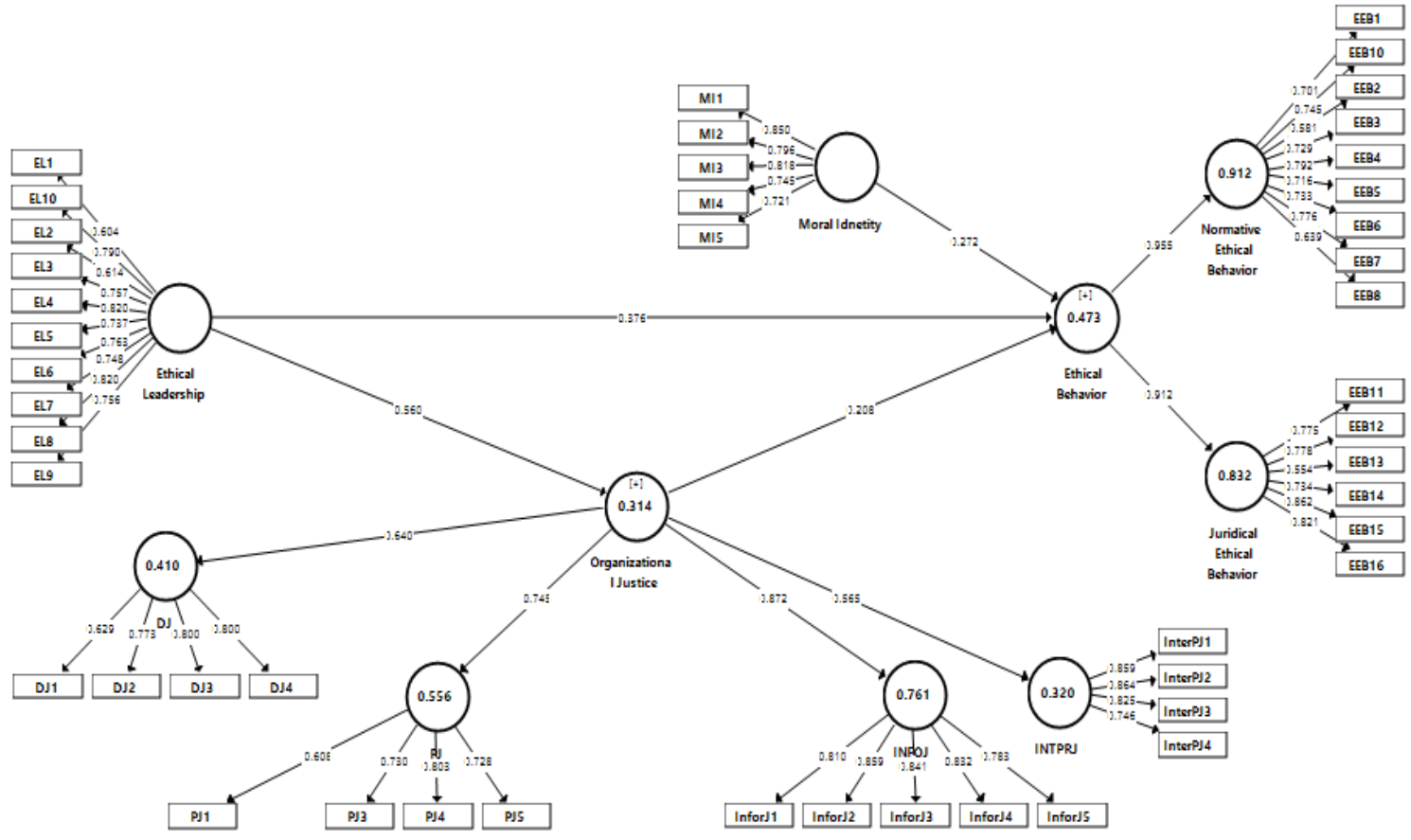

Fig. 1 - Before Marker Variable

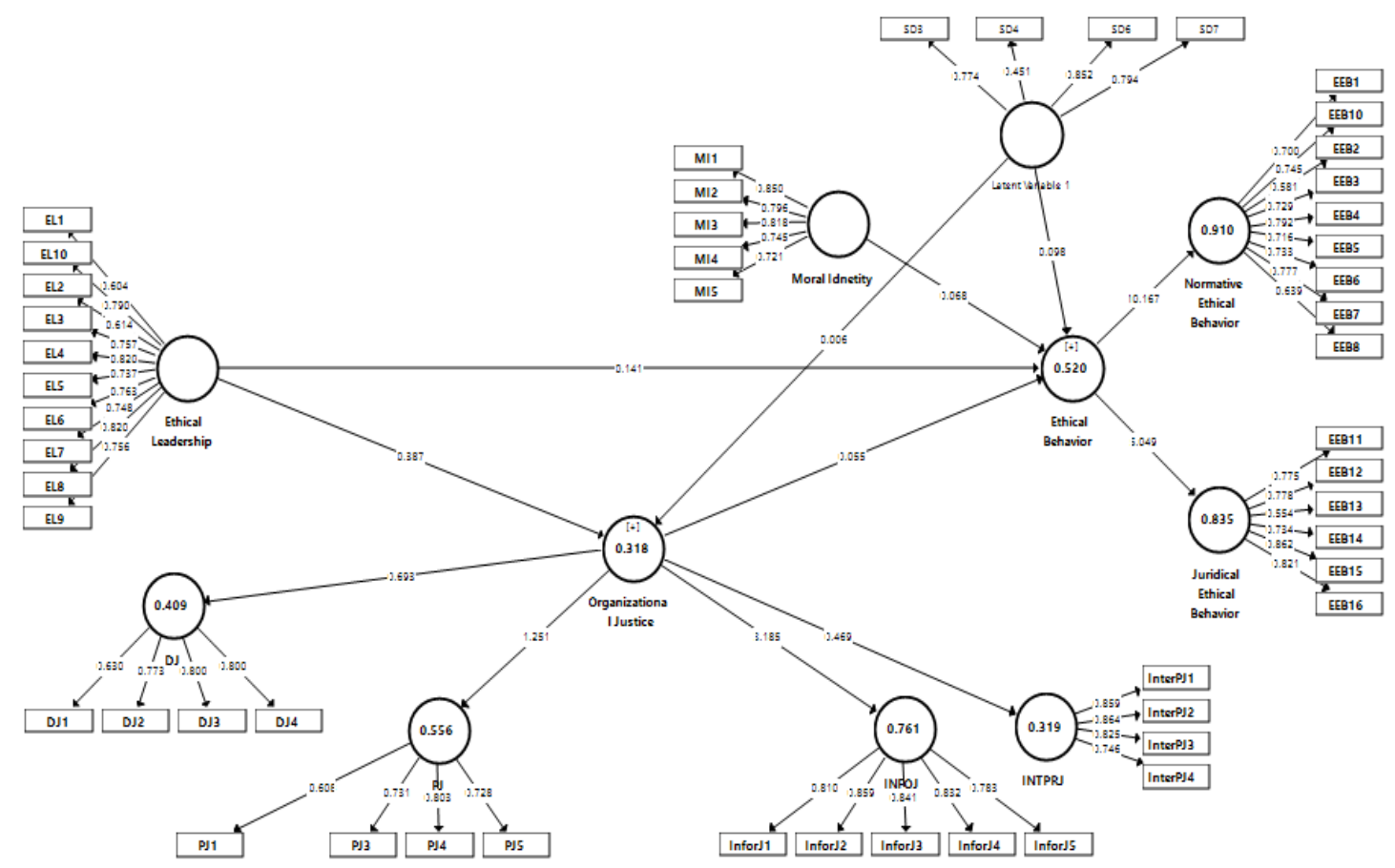

Fig. 2 - After Marker Variable 
Appendix C: Measurement Model (Constructs Reliability and Validity)

\begin{tabular}{|c|c|c|c|c|c|}
\hline First-Order Constructs & Second - Order Constructs & Items & Loading & AVE & $\mathbf{C R}$ \\
\hline \multirow[t]{10}{*}{ Ethical Leadership } & & EL1 & 0.604 & 0.554 & 0.925 \\
\hline & & EL2 & 0.614 & & \\
\hline & & EL3 & 0.757 & & \\
\hline & & EL4 & 0.820 & & \\
\hline & & EL5 & 0.737 & & \\
\hline & & EL6 & 0.763 & & \\
\hline & & EL7 & 0.748 & & \\
\hline & & EL8 & 0.820 & & \\
\hline & & EL9 & 0.756 & & \\
\hline & & EL10 & 0.790 & & \\
\hline \multirow[t]{4}{*}{ Distributive Justice } & & DJ1 & 0.629 & 0.568 & 0.839 \\
\hline & & $\mathrm{DJ} 2$ & 0.773 & & \\
\hline & & DJ3 & 0.800 & & \\
\hline & & DJ4 & 0.800 & & \\
\hline \multirow[t]{4}{*}{ Procedural Justice } & & PJ1 & 0.608 & 0.520 & 0.811 \\
\hline & & $\mathrm{PJ} 3$ & 0.730 & & \\
\hline & & PJ4 & 0.803 & & \\
\hline & & PJ5 & 0.728 & & \\
\hline \multirow[t]{5}{*}{ Informational Justice } & & InforJ1 & 0.810 & 0.681 & 0.914 \\
\hline & & InforJ 2 & 0.859 & & \\
\hline & & InforJ3 & 0.841 & & \\
\hline & & InforJ4 & 0.832 & & \\
\hline & & InforJ5 & 0.783 & & \\
\hline \multirow[t]{8}{*}{ Interpersonal Justice } & & InterPJ1 & 0.859 & 0.680 & 0.895 \\
\hline & & InterPJ2 & 0.864 & & \\
\hline & & InterPJ3 & 0.825 & & \\
\hline & & InterPJ4 & 0.746 & & \\
\hline & Organizational Justice & Distributive Justice & 0.640 & 0.511 & 0.803 \\
\hline & & Procedural Justice & 0.745 & & \\
\hline & & Interpersonal Justice & 0.565 & & \\
\hline & & Informational Justice & 0.872 & & \\
\hline \multirow[t]{5}{*}{ Moral Identity } & & MI1 & 0.850 & 0.620 & 0.890 \\
\hline & & MI2 & 0.796 & & \\
\hline & & MI3 & 0.818 & & \\
\hline & & MI4 & 0.745 & & \\
\hline & & MI5 & 0.721 & & \\
\hline & & & & & \\
\hline
\end{tabular}




\begin{tabular}{|c|c|c|c|c|c|}
\hline \multirow[t]{9}{*}{$\begin{array}{c}\text { Normative Ethical } \\
\text { Behavior }\end{array}$} & & EEB1 & 0.701 & 0.512 & 0.903 \\
\hline & & EEB2 & 0.581 & & \\
\hline & & EEB3 & 0.729 & & \\
\hline & & EEB4 & 0.792 & & \\
\hline & & EEB5 & 0.716 & & \\
\hline & & EEB6 & 0.733 & & \\
\hline & & EEB7 & 0.776 & & \\
\hline & & EEB8 & 0.639 & & \\
\hline & & EEB10 & 0.745 & & \\
\hline \multirow[t]{8}{*}{$\begin{array}{c}\begin{array}{c}\text { Juridical Ethical } \\
\text { Behavior }\end{array} \\
\end{array}$} & & EEB11 & 0.775 & 0.578 & 0.890 \\
\hline & & EEB12 & 0.778 & & \\
\hline & & EEB13 & 0.554 & & \\
\hline & & EEB14 & 0.734 & & \\
\hline & & EEB15 & 0.862 & & \\
\hline & & EEB16 & 0.821 & & \\
\hline & Ethical Behavior & $\begin{array}{c}\text { Normative Ethical } \\
\text { Behavior }\end{array}$ & 0.955 & 0.872 & 0.932 \\
\hline & & $\begin{array}{c}\text { Juridical Ethical } \\
\text { Behavior }\end{array}$ & 0.912 & & \\
\hline
\end{tabular}

Note: $\mathrm{AVE}=$ Average Variance Extracted; $\mathrm{CR}=$ Composite Reliability

\section{References}

Abdullah, A., \& Halim, F. W. (2016). The influence of work ethic and counterproductive work behaviour of civil servants. Journal of Technology Management and Business, 3(1).

Al Halbusi, H., Tehseen, S., Hamid, F. A. H., \& Afthanorhan, A. (2018). A Study of Organizational Justice on the Trust in Organization under the Mediating Role of Ethical Leadership. Journal of ethics and leadership, 2, (4).

Al Halbusi, H., Ismail, M. N. B., \& Omar, S. B. (2019). A Conceptual Proposal: Ethical Leadership Moderates the Effect of Organizational Justice on Ethical Employee Behavior. Kuwait Chapter of the Arabian Journal of Business and Management Review, 8(1), 10-19.

Adams, J. S. (1963). Towards an understanding of inequity. The Journal of Abnormal and Social Psychology, 67(5), 422.

Albaum, G., \& Peterson, R. A. (2006). Ethical attitudes of future business leaders: Do they vary by gender and religiosity? Business \& Society, 45(3), 300-321.

Ambrose, M. L., \& Schminke, M. (2009). The role of overall justice judgments in organizational justice research: a test of mediation. Journal of applied psychology, 94(2), 491.

Anderson, J. C., \& Gerbing, D. W. (1988). Structural equation modeling in practice: A review and recommended twostep approach. Psychological bulletin, 103(3), 411.

Angelidis, J., \& Ibrahim, N. A. (2011). The impact of emotional intelligence on the ethical judgment of managers. Journal of Business Ethics, 99(1), 111-119.

Aquino, K., \& Reed II, A. (2002). The self-importance of moral identity. Journal of personality and social psychology, 83(6), 1423. 
Aquino, K., Freeman, D., Reed II, A., Lim, V. K., \& Felps, W. (2009). Testing a social-cognitive model of moral behavior: the interactive influence of situations and moral identity centrality. Journal of personality and social psychology, 97(1), 123.

Ashforth, B. E., \& Mael, F. (1989). Social identity theory and the organization. Academy of management review, 14(1), 20-39.

Barclay, D., Higgins, C., \& Thompson, R. (1995). The Partial Least Squares (pls) Approach to Casual Modeling: Personal Computer Adoption Ans Use as an Illustration.

Bass, B. M. (1999). Two decades of research and development in transformational leadership. European journal of work and organizational psychology, 8(1), 9-32.

Bergman, R. (2002). Why be moral? A conceptual model from developmental psychology. Human development, 45(2), 104-124.

Bies, R., \& Moag, R. (1986). Interactional justice: Communication criteria of fairness in: RJ Lewicki, BH Sheppard, MH Bazerman (eds.) Research on negotiations in organizations (pp. 43-55): Greenwich: 1JAI Press.

Blasi, A. (1984). Moral identity: Its role in moral functioning. Morality, moral behavior, and moral development, 128139.

Blasi, A. (1990). Kohlberg's theory and moral motivation. New Directions for Child and Adolescent Development, 1990(47), 51-57.

Blasi, A. (2004). Moral functioning: Moral understanding and personality. Moral development, self, and identity, 335347.

Blau, P. (1964). Exchange and power in social life. Routledge.

Brislin, R. W. (1980). Translation and content analysis of oral and written materials. In H. C. Triandis \& J. W. Berry (Eds.), Handbook of cross-cultural psychology: Methodology (pp. 389-444). Boston: Allyn \& Bacon.

Brown, M. E. (2007). Misconceptions of Ethical Leadership: How to Avoid Potential Pitfalls. Organizational Dynamics, 36(2), 140-155.

Brown, M. E., \& Treviño, L. K. (2006). Ethical leadership: A review and future directions. The leadership quarterly, 17(6), 595-616.

Brown, M. E., \& Treviño, L. K. (2014). Do role models matter? An investigation of role modeling as an antecedent of perceived ethical leadership. Journal of Business Ethics, 122(4), 587-598.

Brown, M. E., Treviño, L. K., \& Harrison, D. A. (2005). Ethical leadership: A social learning perspective for construct development and testing. Organizational behavior and human decision processes, 97(2), 117-134.

Burke, C. S., Stagl, K. C., Klein, C., Goodwin, G. F., Salas, E., \& Halpin, S. M. (2006). What type of leadership behaviors are functional in teams? A meta-analysis. The leadership quarterly, 17(3), 288-307.

Burney, L. L., Henle, C. A., \& Widener, S. K. (2009). A path model examining the relations among strategic performance measurement system characteristics, organizational justice, and extra-and in-role performance. Accounting, Organizations and Society, 34(3), 305-321.

Burns, J. M. (1978). Leadership New York. NY: Harper and Row Publishers.

Carlson, S. (1951). Executive behaviour: a study of the work load and the working methods of managing directors. Arno Press.

Certuche, U. B., Lopez, M. D. R., \& Vasquez, L. M. L. (2019). Design of a Serious Game to Teach Organizational Ethical Leadership. In Developments in Business Simulation and Experiential Learning: Proceedings of the Annual ABSEL conference (Vol. 46). 
Chin, W. W., Thatcher, J. B., Wright, R. T., \& Steel, D. (2013). Controlling for common method variance in PLS analysis: the measured latent marker variable approach New perspectives in partial least squares and related methods (pp. 231-239): Springer.

Cohen, J., 1988. Statistical Power Analysis for the Behavioral Sciences, second ed. Routledge, New York.

Colquitt, J. A. (2001). On the dimensionality of organizational justice: a construct validation of a measure. Journal of applied psychology, 86(3), 386.

Colquitt, J. A., Greenberg, J., (2003). Organizational justice: A fair assessment of the state of the literature. Organizational behavior: The state of the science, 159-200.

Cropanzano, R., \& Greenberg, J. (1997). Progress in organizational justice: Tunneling through the maze. International review of industrial and organizational psychology, 12, 317-372.

Cropanzano, R., Byrne, Z. S., Bobocel, D. R., \& Rupp, D. E. (2001). Moral virtues, fairness heuristics, social entities, and other denizens of organizational justice. Journal of Vocational Behavior, 58(2), 164-209.

Crowne, D. P., \& Marlowe, D. (1960). A new scale of social desirability independent of psychopathology. Journal of consulting psychology, 24(4), 349.

Demirtas, O. (2015). Ethical leadership influence at organizations: Evidence from the field. Journal of Business Ethics, 126(2), 273-284.

Detert, J. R., Treviño, L. K., \& Sweitzer, V. L. (2008). Moral disengagement in ethical decision making: a study of antecedents and outcomes. Journal of applied psychology, 93(2), 374.

Dickson, M. W., Smith, D. B., Grojean, M. W., \& Ehrhart, M. (2001). An organizational climate regarding ethics: The outcome of leader values and the practices that reflect them. The Leadership Quarterly, 12(2), 197-217.

Elamin, A. M., \& Alomaim, N. (2011). Does organizational justice influence job satisfaction and self-perceived performance in Saudi Arabia work environment? International Management Review, 7(1), 38.

Eubanks, D. L., Brown, A. D., \& Ybema, S. (2012). Leadership, identity, and ethics. Journal of Business Ethics, 107(1), 1-3.

Ferrell, O. C., Fraedrich, J., \& Ferrell, L. (2000). Business ethics: Ethical decision making and cases (4th ed.). New York: Houghton Mifflin Inc.

Fischer, D. G., \& Fick, C. (1993). Measuring social desirability: Short forms of the Marlowe-Crowne social desirability scale. Educational and Psychological Measurement, 53(2), 417-424.

Flynn, B. B., Sakakibara, S., Schroeder, R. G., Bates, K. A., \& Flynn, E. J. (1990). Empirical research methods in operations management. Journal of operations management, 9(2), 250-284.

Folger, R. G., \& Cropanzano, R. (1998). Organizational justice and human resource management (Vol. 7): Sage. Folger, R., Cropanzano, R., \& Goldman, B. (2005). What is the relationship between justice and morality? Handbook of organizational justice, 215, 215-245.

Fraedrich, J. P. (1993). The ethical behavior of retail managers. Journal of Business Ethics, 12(3), 207-218.

Gold, A. H., Malhotra, A., \& Segars, A. H. (2001). Knowledge management: An organizational capabilities perspective. Journal of management information systems, 18(1), 185-214.

Greenberg, J. (1990). Organizational justice: Yesterday, today, and tomorrow. Journal of management, 16(2), $399-432$. Greenberg, J. (2001). Studying organizational justice cross-culturally: Fundamental challenges. International Journal of Conflict Management, 12(4), 365-375.

Hair J.F., Sarstedt, M., Hopkins, L., \& G. Kuppelwieser, V. (2014). Partial least squares structural equation modeling (PLS-SEM) An emerging tool in business research. European Business Review, 26(2), 106-121. 
Hair, J.F., Black, W.C., Babin, B.J., Anderson, R.E., (2010). Multivariate Data Analysis, seventh ed. Pearson, New York.

Hair, J.F., Hult, G.T.M., Ringle, C., Sarstedt, M., (2017). A Primeron Partial Least Squares Structural Equation Modeling (PLS-SEM), seconded. SAGE, London: Thousand Oaks.

Hales, S. (1985). The inadvertent rediscovery of self in social psychology. Journal for the Theory of Social Behaviour, 15(3), 237-282.

Hardy, S. A., \& Carlo, G. (2005). Identity as a source of moral motivation. Human development, 48(4), $232-256$.

Hart, D., Atkins, R., \& Ford, D. (1998). Urban America as a context for the development of moral identity in adolescence. Journal of social issues, 54(3), 513-530.

Heller, F. A. (1971). Managerial decision-making: A study of leadership styles and power-sharing among senior managers. Taylor \& Francis.

Henseler, J., \& Chin, W. W. (2010). A comparison of approaches for the analysis of interaction effects between latent variables using partial least squares path modeling. Structural Equation Modeling, 17(1), 82-109.

Henseler, J., Ringle, C. M., \& Sarstedt, M. (2015). A new criterion for assessing discriminant validity in variance-based structural equation modeling. Journal of the Academy of Marketing Science, 43(1), 115-135.

Hofstede, G. (1984). Culture's consequences: International differences in work-related values (Vol. 5). sage.

Holtz, B. C., \& Harold, C. M. (2013). Interpersonal justice and deviance: The moderating effects of interpersonal justice values and justice orientation. Journal of management, 39(2), 339-365.

Karam, E. P., Hu, J., Davison, R. B., Juravich, M., Nahrgang, J. D., Humphrey, S. E., \& Scott DeRue, D. (2019). Illuminating the 'Face'of Justice: A Meta- Analytic Examination of Leadership and Organizational Justice. Journal of Management Studies, 56(1), 134-171.

Kelley, H. H., \& Stahelski, A. J. (1970). Social interaction basis of cooperators' and competitors' beliefs about others. Journal of personality and social psychology, 16(1), 66.

Kimmel, M. J. (1981). Senior leadership: An annotated bibliography of the military and nonmilitary literature (No. ARI-TR-532). ARMY RESEARCH INST FOR THE BEHAVIORAL AND SOCIAL SCIENCES ALEXANDRIA VA.

Kline, R.B., (2010). Principles and Practice of Structural Equation Modeling, third ed. The Guilford Press, New York. Koh, H. C., \& El'Fred, H. (2001). The link between organizational ethics and job satisfaction: A study of managers in Singapore. Journal of Business Ethics, 29(4), 309-324.

Koopman, J., Scott, B. A., Matta, F. K., Conlon, D. E., Dennerlein, T., Hollensbe, M. L., ... \& Stoverink, A. (2019). Ethical leadership as a substitute for justice enactment: An information-processing perspective. The Journal of applied psychology.

Kuntz, J. R. C., Kuntz, J. R., Elenkov, D., \& Nabirukhina, A. (2013). Characterizing ethical cases: A cross-cultural investigation of individual differences, organisational climate, and leadership on ethical decision-making. Journal of Business Ethics, 113(2), 317-331.

Lambert, E. G., Keena, L. D., Leone, M., May, D., \& Haynes, S. H. (2019). The effects of distributive and procedural justice on job satisfaction and organizational commitment of correctional staff. The Social Science Journal.

Lapsley, D. K., \& Lasky, B. (2001). Prototypic moral character. Identity: An International Journal of Theory and Research, 1(4), 345-363.

Lapsley, D. K., \& Lasky, B. (2001). Prototypic moral character. Identity: An International Journal of Theory and Research, 1(4), 345-363.

Lin, X. W., Che, H. S., \& Leung, K. (2009). The role of leader morality in the interaction effect of procedural justice and outcome favorability. Journal of Applied Social Psychology, 39(7), 1536-1561. 
Lind, E. A. (2001). Fairness heuristic theory: Justice judgments as pivotal cognitions in organizational relations. Advances in organizational justice, 56(8).

Loi, R., Lam, L. W., \& Chan, K. W. (2012). Coping with job insecurity: The role of procedural justice, ethical leadership and power distance orientation. Journal of Business Ethics, 108(3), 361-372.

Loi, R., Mao, Y., \& Ngo, H. Y. (2009). Linking leader-member exchange and employee work outcomes: The mediating role of organizational social and economic exchange. Management and Organization Review, 5(3), 401-422.

Lu, C. S., \& Yang, C. S. (2010). Safety leadership and safety behavior in container terminal operations. Safety science, $48(2), 123-134$.

Lu, C.-S., \& Lin, C.-C. (2014). The effects of ethical leadership and ethical climate on employee ethical behavior in the international port context. Journal of Business Ethics, 124(2), 209-223.

Manz, C. C., Anand, V., Joshi, M., \& Manz, K. P. (2008). Emerging paradoxes in executive leadership: A theoretical interpretation of the tensions between corruption and virtuous values. The Leadership Quarterly, 19(3), 385-392.

Mayer, D. M., Kuenzi, M., Greenbaum, R., Bardes, M., \& Salvador, R. B. (2009). How low does ethical leadership flow? Test of a trickle-down model. Organizational behavior and human decision processes, 108(1), 1-13.

McClelland, G. H., \& Judd, C. M. (1993). Statistical difficulties of detecting interactions and moderator effects. Psychological bulletin, 114(2), 376.

Mehta, S. N. (2003). MCI: Is being good good enough? Fortune, 148(9), 117-117.

Mitchell, M. S., \& Ambrose, M. L. (2007). Abusive supervision and workplace deviance and the moderating effects of negative reciprocity beliefs. Journal of applied psychology, 92(4), 1159.

Mitchell, M. S., Reynolds, S. J., \& Treviño, L. K. (2017). The study of behavioral ethics within organizations. Personnel psychology, 70(2), 313-314.

Nelissen, R. M., Dijker, A. J., \& de Vries, N. K. (2007). Emotions and goals: Assessing relations between values and emotions. Cognition and Emotion, 21(4), 902-911.

Neubert, M. J., Carlson, D. S., Kacmar, K. M., Roberts, J. A., \& Chonko, L. B. (2009). The virtuous influence of ethical leadership behavior: Evidence from the field. Journal of Business Ethics, 90(2), 157-170.

Ofori, G. (2009). Ethical leadership: Examining the relationships with full range leadership model, employee outcomes, and organizational culture. Journal of Business Ethics, 90(4), 533.

Ones, D. S., \& Dilchert, S. (2012). Environmental sustainability at work: A call to action. Industrial and Organizational Psychology, 5(4), 444-466.

Oshio, T., \& Kobayashi, M. (2009). Income inequality, area-level poverty, perceived aversion to inequality, and selfrated health in Japan. Social Science \& Medicine, 69(3), 317-326.

Padilla, A., Hogan, R., \& Kaiser, R. B. (2007). The toxic triangle: Destructive leaders, susceptible followers, and conducive environments. The Leadership Quarterly, 18(3), 176-194.

Phillips, R. L., \& Hunt, J. G. (1992). Strategic leadership: A multiorganizational-level perspective. In This book is based on contributions prepared for a conference held at Carlisle Barracks, PA, Feb 11-14, 1991. Quorum Books/Greenwood Publishing Group.

Podsakoff, P. M., MacKenzie, S. B., Lee, J.-Y., \& Podsakoff, N. P. (2003). Common method biases in behavioral research: A critical review of the literature and recommended remedies. Journal of applied psychology, 88(5), 879.

Preacher, K. J., \& Hayes, A. F. (2004). SPSS and SAS procedures for estimating indirect effects in simple mediation models. Behavior research methods, instruments, \& computers, 36(4), 717-731. 
Preacher, K., \& Hayes, A. (2008). Asymptotic and resampling strategies for assessing and comparing indirect effects in multiple mediator models. Behaviour Research Methods, 40, 879-891. The sage handbook of advanced data analysis methods for communication research, 1354.

Premeaux, S. (2009). The link between management behavior and ethical philosophy in the wake of the Enron convictions. Journal of Business Ethics, 85(1), 13-25.

Rawls, J. (1971). A Theory of Justice (Cambridge, MA: Belknap); 1996. Political Liberalism, 109-31.

Resick, C. J., Hanges, P. J., Dickson, M. W., \& Mitchelson, J. K. (2006). A cross-cultural examination of the endorsement of ethical leadership. Journal of Business Ethics, 63(4), 345-359.

Reynolds, S. J., \& Ceranic, T. L. (2007). The effects of moral judgment and moral identity on moral behavior: An empirical examination of the moral individual. Journal of applied psychology, 92(6), 1610.

Rhoades, L., Eisenberger, R., \& Armeli, S. (2001). Affective commitment to the organization: The contribution of perceived organizational support. Journal of applied psychology, 86(5), 825.

Ringle, C.M., Wende, S., Becker, J.-M., 2015. SmartPLS 3. Bonningstedt: SmartPLS. Retrieved October 30, 2018, from http://www.smartpls.com.

Sama, L. M., \& Shoaf, V. (2008). Ethical leadership for the professions: Fostering a moral community. Journal of Business Ethics, 78(1-2), 39-46.

Schaubroeck, J., Walumbwa, F. O., Ganster, D. C., \& Kepes, S. (2007). Destructive leader traits and the neutralizing influence of an "enriched” job. The Leadership Quarterly, 18(3), 236-251.

Schumacker, R.E., Lomax, R.G., (2004). A Beginner's Guide to Structural Equation Modeling. Lawrence Erlbaum, New York.

Shah, N., Anwar, S., \& Irani, Z. (2017). The impact of organisational justice on ethical behaviour. International Journal of Business Innovation and Research, 12(2), 240-258.

Shao, R., Aquino, K., \& Freeman, D. (2008). Beyond moral reasoning: A review of moral identity research and its implications for business ethics. Business Ethics Quarterly, 18(4), 513-540.

Skitka, L. J., \& Bauman, C. W. (2008). Is Morality Always an Organizational Good? A Review of Current Conceptions of Morality in Organizational and Social Justice Theory and Research. Emerging perspectives on managing organizational justice, 1-28.

Stead, W. E., Worrell, D. L., \& Stead, J. G. (1990). An integrative model for understanding and managing ethical behavior in business organizations. Journal of Business Ethics, 9(3), 233-242.

Steensma, H., \& Visser, E. (2007). Procedural justice and supervisors' personal power bases: Effects on employees' perceptions of performance appraisal sessions, commitment, and motivation. Journal of Collective Negotiations, 31(2), 101-118.

Sullivan, G. M., \& Feinn, R. (2012). Using effect size - or why the P value is not enough. Journal of graduate medical education, 4(3), 279-282.

Tanghe, J., Wisse, B., \& Van Der Flier, H. (2010). The formation of group affects and team effectiveness: The moderating role of identification. British Journal of Management, 21(2), 340-358.

Tehseen, S., Ramayah, T., \& Sajilan, S. (2017). Testing and controlling for common method variance: a review of available methods. Journal of Management Sciences, 4(2), 142-168.

Tenbrunsel, A., \& Smith- Crowe, K. (2008). Ethical decision making: Where we've been and where we're going. The Academy of Management Annals, 2 (1), 545-607. 
Tepper, B. J., Carr, J. C., Breaux, D. M., Geider, S., Hu, C., \& Hua, W. (2009). Abusive supervision, intentions to quit, and employees' workplace deviance: A power/dependence analysis. Organizational behavior and human decision processes, 109(2), 156-167.

Thau, S., \& Mitchell, M. S. (2010). Self-gain or self-regulation impairment? Tests of competing explanations of the supervisor abuse and employee deviance relationship through perceptions of distributive justice. Journal of applied psychology, 95(6), 1009.

Trevino, L. K., \& Brown, M. E. (2004). Managing to be ethical: Debunking five business ethics myths. Academy of management perspectives, 18(2), 69-81.

Treviño, L. K., Den Nieuwenboer, N. A., \& Kish-Gephart, J. J. (2014). (Un) ethical behavior in organizations. Annual review of psychology, 65, 635-660.

Viswesvaran, C., Deshpande, S. P., \& Joseph, J. (1998). Job satisfaction as a function of top management support for ethical behavior: A study of Indian managers. Journal of Business Ethics, 17(4), 365-371.

Wetzels, M., Odekerken-Schröder, G., \& Van Oppen, C. (2009). Using PLS path modeling for assessing hierarchical construct models: Guidelines and empirical illustration. MIS quarterly, 177-195.

Wiernik, B. M., Rüger, H., \& Ones, D. S. (2018). Advancing expatriate research in public and private sectors. Managing Expatriates: Success Factors in Private and Public Domains, Series on Population Studies, 50.

Xu, A. J., Loi, R., \& Ngo, H.-y. (2016). Ethical leadership behavior and employee justice perceptions: The mediating role of trust in organization. Journal of Business Ethics, 134(3), 493-504. 